\title{
F. Scott Fitzgerald's \\ Racial Angles and the \\ Business of Literary Greatness
}




\section{American Literature Readings \\ IN THE 2IST CENTURY}

\section{Series Editor: Linda Wagner-Martin}

American Literature Readings in the 21st Century publishes works by contemporary critics that help shape critical opinion regarding literature of the nineteenth and twentieth century in the United States.

\section{Published by Palgrave Macmillan:}

Freak Shows in Modern American Imagination: Constructing the Damaged Body from Willa Cather to Truman Capote

By Thomas Fahy

Arab American Literary Fictions, Cultures, and Politics

By Steven Salaita

Women e Race in Contemporary U.S. Writing: From Faulkner to Morrison By Kelly Lynch Reames

American Political Poetry in the 21st Century

By Michael Dowdy

Science and Technology in the Age of Hawthorne, Melville, Twain, and James: Thinking and Writing Electricity

By Sam Halliday

Sex, Race, and Family in Contemporary American Short Stories

By Melissa Bostrom

Democracy in Contemporary U.S. Women's Poetry (forthcoming)

By Nicky Marsh

James Merrill and W.H. Auden: Homosexuality and Poetic Influence (forthcoming)

By Piotr K. Gwiazda

Contemporary U.S. Latino/a Literary Criticism (forthcoming)

Edited by Lyn Di Iorio Sandín and Richard Perez 


\section{F. Scott Fitzgerald's Racial Angles and the Business of Literary Greatness}

by

Michael Nowlin 


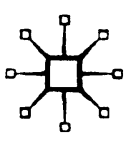

F. SCOTT FITZGERALD'S RACIAL ANGLES AND THE BUSINESS OF LITERARY GREATNESS (C) Michael Nowlin, 2007.

Softcover reprint of the hardcover 1st edition 2007 978-1-4039-7671-0

All rights reserved. No part of this book may be used or reproduced in any manner whatsoever without written permission except in the case of brief quotations embodied in critical articles or reviews.

First published in 2007 by

PALGRAVE MACMILLAN'M

175 Fifth Avenue, New York, N.Y. 10010 and

Houndmills, Basingstoke, Hampshire, England RG21 6XS

Companies and representatives throughout the world.

PALGRAVE MACMILLAN is the global academic imprint of the Palgrave Macmillan division of St. Martin's Press, LLC and of Palgrave Macmillan Ltd. Macmillan ${ }^{\circledR}$ is a registered trademark in the United States, United Kingdom and other countries. Palgrave is a registered trademark in the European Union and other countries.

ISBN 978-1-349-73802-1 ISBN 978-1-137-11647-5 (eBook)

DOI 10.1007/978-1-137-11647-5

Library of Congress Cataloging-in-Publication Data

Nowlin, Michael, 1962-

F. Scott Fitzgerald's racial angles and the business of literary greatness / Michael Nowlin.

p. $\mathrm{cm}$.- (American literature readings in the 21st century) Includes index.

1. Fitzgerald, F. Scott (Francis Scott), 1896-1940-Criticism and interpretation. 2. Fitzgerald, F. Scott (Francis Scott), 1896-1940Philosophy. 3. National characteristics, American, in literature. 4. Race in literature. 5. Literature and history-United States. 6. AuthorshipHistory-20th century. 7. Popular culture-United States-History20th century. I. Title.

PS3511.19Z755 2007

$813^{\prime} .52-\mathrm{dc} 22$

2007060031

A catalogue record for this book is available from the British Library.

Design by Newgen Imaging Systems (P) Ltd., Chennai, India.

First edition: July 2007

10987654321

Transferred to Digital Printing 2011 
For

Caroline,

Colin \& Renata

with love and joy 

It would be a misfortune also to seem to say that the author who misses popularity is necessarily an artist, or that even temporary success is not to be admired. But in American letters we are beginning to wonder why our great successes are so transitory; why a writer who sells more copies of his first book than did Thackeray or Dickens, does not continue like them to reach a large public with succeeding books; and why he does not, like them, continue to be read after he has ceased to write.

John Erskine, “Spotlight or Fame?," Bookman, July 1922

Great art is the contempt of a great man for small art.

F. Scott Fitzgerald, Notebooks 



\section{Contents}

Introduction F. Scott Fitzgerald, "the Cultural World," and the Lure of the American Scene

1 The Racial Make-up of the Entertainer in Two Early Post Stories

2 Early Success, Holy Irony, and the Cultural Field of The Beautiful and Damned

3 "Trashy Imaginings" and The "Greatness" of The Great Gatsby

4 "The Model for the Age": The Distinction of Tender is the Night

5 “A Gentile's Tragedy": Bearing the Word about Hollywood in The Love of the Last Tycoon

Conclusion "Dearly Beloved" and the Black Face of Fitzgerald's Ambition

Notes 



\section{ACKNOWLEDGMENTS}

I would like to thank the Social Science and Humanities Research Council of Canada for the generous Standard Research Grant that enabled me to do the research for this project and present early parts of it at academic conferences. The SSHRC grant also allowed me to hire a series of valuable research assistants. I acknowledge the good work here of Julie Brennan, Madeline Walker, and Jennifer Douglas.

An earlier version of Chapter 1 appeared as part of "F. Scott Fitzgerald's Elite Syncopations: The Racial Make-up of the Entertainer," in English Studies in Canada 26.4 (2000). An earlier, shorter version of Chapter 5 appeared in the F. Scott Fitzgerald Review 2 (2003). I thank the editors of these journals for granting me permission to re-print this material.

The University of Virginia Library generously granted me permission to reproduce a good example of Fitzgerald's blackface "trademark" in Chapter I. I want especially to thank Edward Gaynor, Associate Director of the Albert and Shirley Small Special Collections Library, for his help in this matter.

Linda Wagner-Martin has both indirectly and directly supported this project from its inception. I am immensely grateful for her encouragement, and her help in bringing the book to Palgrave-Macmillan. I am equally grateful for the critical and moral support of my colleague Luke Carson, who read over and forced me to clarify substantial portions of the manuscript. If points remain fuzzy, I have only myself to blame.

Other acknowledgments are more personal. The moral, intellectual, and financial support of family members has been indispensable, especially that of my brother Christopher, who has been a vital intellectual companion for the past two decades; my mother Barbara Hoyt, who shares my love of great writing and has always backed my dedication to studying it; and my stepfather Martin Hoyt, who probably forgets that he bought me my first copy of The Great Gatsby over thirty years ago instead of taking me to the movie. 
Finally, I want to thank my beloved companion Caroline Baldwin, not only for her help in indexing, proofreading, and critically commenting on sections of the book, but for the more than ten years of love and support she has given me while I intermittently worked on the project, and her unwavering belief that I could get it done. 